\title{
Could innovative teams provide the necessary flexibility to compete in the current context?
}

\section{¿Podrían los equipos innovadores proporcionar la flexibilidad necesaria para competir en el contexto actual?}

\author{
Mercedes Rubio Andrés ${ }^{1}$ \\ Santiago Gutiérrez Broncano ${ }^{2}$ \\ Juan Nicolás Montoya Monsalve ${ }^{3}$ \\ CEU San Pablo University (Spain) \\ University of Castilla-La Mancha (Spain) \\ National University of Colombia (Colombia)
}

Recibido el 20 de noviembre de 2013, aceptado el 6 de mayo de 2014

$\mathrm{N}^{\mathrm{o}}$ de clasificación JEL: M 12, M 21

DOI: $10.5295 / \mathrm{cdg} .130446 \mathrm{mr}$

\begin{abstract}
:
In the modern era firms should look for a sustainable and profitable business model. They operate in highly volatile and competitive markets. Innovation is a key element that allows firms to survive in these complex environments. Accordingly, some companies are developing human resource models that align to the actual competitive context. For instance, they establish democratic systems, flexible work practices, they focus on responsibility and initiative and increase the self-control of team members. In this framework, firms tend to use resources such as creativity, capacity for innovation or development of human talent. Therefore, innovative teams are able to adapt and react to turbulent, complex and dynamic environments, which allow them to handle in a more efficient way several subtasks. This fact gives rise to a higher effectiveness in the activities of firms. This paper analyze the characteristics and performance of multifunctional teams, virtual teams, open-innovation teams and self-managing teams. It also study the case of Semco, a company that is characterized by its innovative practices in human resources management and focus on responsibility and initiative and increase the self-control of team members.
\end{abstract}

Keyboards:

Work teams, innovative team, high performance human resource practices, innovation, case study.

\footnotetext{
1 Faculty of Economics and Business. CEU San Pablo University. C/ Julián Romea, 23, ed. B, 28003, Madrid (Spain).mrubio@ceu.es

2 Faculty of Social Sciences. University of Castilla-La Mancha. Avda. Real Fábrica de Seda, s/n, 45600, Talavera de la Reina - Toledo (Spain). santiago.gutierrez@uclm.es

3 Faculty of Administration. National University of Colombia. Carrera 27 \#64-60 Manizales. nmontoyamo@unal. edu.co
} 
Could innovative teams provide the necessary flexibility to compete in the current context?

\section{Resumen:}

En la era moderna las empresas deben buscar un modelo de negocio sostenible y rentable, dado que desarrollan su actividad en mercados altamente volátiles y competitivos. La innovación es un elemento clave que permite a las empresas sobrevivir en estos ambientes complejos. En consecuencia, algunas empresas utilizan un modelo de recursos humanos de acuerdo con la situación actual y establecen un sistema democrático, con el trabajo flexible, centrándose en la responsabilidad y la iniciativa y aumentando el autocontrol de los miembros del equipo. Utilizan recursos tales como la creatividad, la capacidad de innovación o el desarrollo del talento humano. En la mayoría de los casos, los equipos innovadores son capaces de adaptarse y reaccionar a los entornos turbulentos, complejos y dinámicos, que les permiten manejar de manera más eficiente varias tareas. En este trabajo analizamos las características y el funcionamiento de los equipos multifuncionales, equipos virtuales, equipos de innovación abierta y los equipos autogestionados, y finalmente nos centramos en un caso de estudio, Semco, una empresa que se caracteriza por sus prácticas innovadoras en la gestión de recursos humanos y centrada en la responsabilidad y la iniciativa y aumentar el autocontrol de los miembros del equipo.

\section{Palabras clave:}

Equipos de trabajo, equipo innovador, prácticas de alto rendimiento de recursos humanos, innovación, estudio de casos. 


\section{INTRODUCTION}

Adaptability is crucially important to organizational success due to environment change (Terreberry, 1968). Through team working, organizations can flexibly adapt and react to turbulent, complex and dynamic environments, and thereby focus their efforts to more efficiently handle subtasks resulting in overall organizational effectiveness (Richter, et. al. 2011). Therefore, these teams are better prepared to tackle the new challenges presented by today's markets (Tushman and O’Reilly, 1997).

Teamwork was seen as a new way to organize work which helped to empower employees and shift decision-making control to the people actually performing task (Levi and Slem, 1995). Now, in order to survive these increasingly complex environments and respond to these new situations, innovation is key. The most advanced organizations are developing new models of organization, based on work groups, which aim to promote innovation and increase their response capacity (King and Anderson, 2002). By development these types of corporate knowledge assets modern companies are able to achieve a sustainable competitive advantage. Resources such as creativity, the capacity for innovation, the development of human talent, the management of teams or leadership, are increasingly used in business management because they generate an improved competitive position for those companies that best develop them and that are able to implement them successfully (Drazin and Schoonhoven, 1996). Moreover some of them are giving to innovation a higher bonus.

Although, there are a variety of factors which relate to successful use of teamwork, we want focus on the human resource model because here there are another set of factors which underlie successful teams. The main objective is study how self managing teams are managed in a company and know what human resource practices can be useful for this implementation.

To do this, firstly, the differences between a work team and a group will be established. Subsequently, the basic characteristics of innovative work teams will be presented, and a particular focus on multifunctional teams, virtual teams, open-innovation teams and selfmanaging teams. Then also high performance work practices are introduced as a model where we can discover new elements, which are important to improve member team's skills.

Finally, through case method study, we try to check how and what high performance work practices implement in a company (SEMCO), to improve the use and the performance of self-managing teams. Analyze Semco as a sustainable and profitable business concept and the human resource model according with innovative teams and if this helps to create a pleasant work's environment, flexibility and increase performance.

\section{WORK TEAMS: MAIN CHARACTERISTICS}

Understanding what are work teams and basic characteristics that they have, is essential to guaranteeing its successful implementation. The problem for many companies is that neither high-ranking directors nor other employees truly understand what it means to work in a team and mistakenly believe that being physically present in the same room is 
enough to ensure a group functions correctly. One frequently mistake is to call the group a team (Isaksen and Lawer, 2002). The simple situation of having one individual with excessive authority, who imposes his/her ideas, prevents effective interaction between the other members of the group. Therefore, it is extremely important to differentiate between what may be called a work team and what is merely a group. Fundamentally, a group is characterized by having members that interact to share information and take decisions, there by facilitating one another's professional development within their area of responsibility. Members of the group are not required to, and do not have the opportunity to carry out collective work that requires the efforts of all, resulting in a lack of synergy in the work they each carry out as there is little or no interdependency between the different functions. While a team, however, is comprised of a reduced number of people with complementary technical and personal skills, that interact to achieve a common objective, the outcome of which is a collective result that is greater than the sum if the individual parts for which they are all responsible. All members are committed to the processes, the common purpose or the goals in their organization (Isaksen and Lawer, 2002).

It should not be forgotten that a work team is one which carries out a number of tasks of collective importance for the organization, through which the structure, composition and functioning of the group are defined (West, 2002). According to this author, these tasks include the autonomy of the team, the opportunities for learning, and the development and the level of participation between the members. Therefore, the end result is that the members of the team identify with the task and achieve greater intrinsic motivation that affects their level of creativity and innovation.

\section{INNOVATIVE TEAMS}

Several authors (e.g. Anderson et al., 2004; Janssen et al., 2004) determine the presence of certain factors that intervene in the innovation process. These factors are fundamentally related, either to the situation in which they are developed (organizational) or to the work teams (Gutiérrez, 2012). There is a particular focus on multifuncional teams, virtual teams, open-innovation teams and self-mananing teams

Companies are constantly increasing the number of tasks that require the collaboration of different departments. To facilitate coordination, companies create multifunctional teams, incorporating members from several different areas, in order to develop and complete these tasks. The team is responsible for planning and carrying out a complex task that requires a high level of coordination and cooperation, and the collective resolution of any problems encountered. These teams are comprised of people trained in different areas, which gives them certain advantages over teams based only on people from one or very few different area. This allows the team to cover numerous wider sources of information to which the different specialists have access.

Multifunctional teams may be created independently from an organization to carry out different tasks and projects, or even to deal with certain clients. The most common situation in which this type of team is used is for the development of a new product, in which the engineering, manufacturing and marketing departments are closely linked. Other examples are the implementation of new IT equipment, the planning of a publicity campaign, the development of a new training programme, etc. 
Some multifunctional teams may be permanently incorporated into the formal structure of an organization, although the majority are temporary and are disbanded once the task they were created for has been completed.

But nowadays, people don't only do their job "on site" but due to new technologies, and other kinds of teams allowing people collaboration on line emerge. During the last years, the number of this type of team, called "virtual teams" has increased. Moreover, some authors foresee a sharp increase in the number of these teams in organizations and even expect them to revolutionize the workplace in the future (Townsend et al., 1998). But really, all teams make at least a part of their job remotely and it has revolutionized the work (Townsend et al., 1998). Virtual teams are teams in which members may be physically a great distance apart from one another, but are able to carry out an intense collaboration through the use of advanced information technology, such as email, video conferencing, IT programmes, groupware, mobile telephones, etc. This allows individuals with unique skills and who are in different places to work on the same project. They are able, therefore, to collaborate without incurring travel costs and without interrupting their lives (Joinson, 2002). But, in virtual teams, channels of communication are much less rich and present more problems when establishing norms and dialects than in direct or face-to-face forms of communication. Is for it, that any new personnel selected must be comfortable with using new technologies and have solid interpersonal skills (Kirkman et al., 2001). Virtual teams are more likely to comprise members with different cultures, work hours, and organizations, which poses new challenges to the leaders of these teams. The lack of contact creates difficulties for tasks such as supervision, influencing members, developing confidence, etc.

Some companies use a new team very different that previous. Open-innovation teams are characterized by adding external sources of knowledge to accelerate and improve the innovation process (De Jong et al., 2008). New network communication technologies have allowed to experience phenomena that would have been impossible just a few years ago.

They are based on the fact that organizations do not have all the necessary talent to improve their innovations, and therefore require the collaboration of stakeholders from outside the company (Chesbrough, 2006). However, it is important to realize that open innovation has its limits with regard to its application, particularly in the type of task and the industrial sector to which it applies (Chesbrough, 2006). It is not always possible to put into practice, nor would it always be desirable to do so. Studies on these types of teams are at an early stage, meaning that there are not yet sufficient findings on which to make valued judgments. In order to manage this open innovation, Boudreau and Lakhani (2009) propose two related models; though collaborative communities or through competitive markets. Collaborative communities are characterized as having social norms and 'weak' rules in order to promote open access to information, transparency and joint development and intellectual property. The best examples are perhaps the Linux operating system, from the Linux Foundation, the web browser Mozilla Firefox, the web server Apache, contributions to Wikis, as well as other open code software initiatives. The main problem presented by some studies is that there is little empirical evidence concerning which practices comprise a coherent system of human resources management oriented towards performance.

Finally, self-managing teams have been used more and more in recent years in the business environment (Kirkman et al., 2001). Some studies (Lawler, 1992) explain that $68 \%$ of the 1000 companies on the Fortune 1000 list make use of this type of team. Self- 
managing teams are non-hierarchical groups of individuals with different and complementary experience and knowledge. Yang and Guy (2011) defined a self managing team as a "relatively autonomous work groups whose members share responsibility and leadership to accomplish their independent task. Their objective is to develop a type of collective knowledge that requires the pooling of individual knowledge (Grant, 1997). Their characteristics include independent tasks, autonomous decision making (Wellis et al, 1991), shared responsibility (Wall et al, 1986) and shared leadership. Sometimes, self-managing teams are also responsible for personnel decisions within the team, such as working hours, the selection and contracting of members, dismissal, and even determining salaries.

This type of innovative teams, are also used in SMEs as a good human resource management to create organizational effectiveness and competitive advantage (Rubio, Gutiérrez and Varona, 2013).

Specifically, the advantages of self-managing teams are team members more committed to the work, an efficient management of labour issues, greater efficiency and job satisfaction, less employee turnover and less absenteeism. The company's competitive advantage is better protected than a situation in which knowledge rests with just one individual (Wright et al., 1994). When the members learn to carry out multiple tasks the team's flexibility increases when resolving problems, the work becomes more interesting and there is an opportunity to learn new skills.

Despite the fact that trade magazines are full of articles describing the successful applications of self-managing teams (Cordery, Mueller and Smith, 1991), some precautions must be taken. There are also criticisms and negative aspects of this type of work, as it does not always produce the desired improvements in performance (Chaston, 1998). Certain resistance has been noted among individuals when it comes to sharing knowledge, which reduces performance.

The results of these teams on research carried out are not always consistent and do not reflect great improvements in performance (Banker et al., 1996; Cohen and Ledford, 1994).

Most studies (Kirkman and Rosen 1999; Cohen and Bailey, 1997; Pearce and Ravlin, 1987) outline some conditions as favouring better results, for example: establishing clear objectives, complex and important tasks, consistent members, access to relevant information, sufficient recognition and remuneration, strong support from superior management, excellent interpersonal skills between members, high level of discretion over work processes and competent and instructive leadership. All of them are aspect related with human resource management.

\section{INNOVATIVE TEAM AND HIGH PERFORMANCE PRACTICES}

High performance practices (Walton, 1985; Wood and Albanese, 1995) or high involvement practices (Huselid, 1995), are also known by some authors as 'soft' managements models of human resources (Guest, 1987; Truss et al., 1997). These terms essentially refer to the planning of human resources management oriented towards the commitment of the employees, involving the active participation of these in decision making and providing the necessary organization support and resources. It stems from the idea that the effect 
produced between capabilities and motivation has a multiplying effect on the value created in the organization.

There are two principal advantages for organizations in implementing systems of human resources management oriented towards performance: firstly, it enables the organization to be more effective (Lawler, 1992) and secondly, it increases the social acceptance of this model in comparison with the traditional taylorist style based on strict control and subordination of the employees (Sashkin, 1984).

Researchers have attempted to determine which best human resources practices have generated the best results by grouping non-traditional practices that have been increasingly used in companies. Ichniowski et al., (1996) cite work flexibility, teamwork, contingent remuneration, empowerment, job security, etc., as practices that generate the greatest level of commitment among employees.

Marchington and Grugulis (2000) presented a model based on the seven practices identified by Pfeffer $(1994,1998)$ as generating success: job security, selective contracting of personnel, teamwork, contingent compensation, extensive training, reduction of status differences and transfer of information.

Table 1

Principal High Performance Human Resources Practices

\begin{tabular}{|c|c|c|}
\hline $\begin{array}{l}\text { HIGH PERFOR- } \\
\text { MANCE PRAC- } \\
\quad \text { TICES }\end{array}$ & DESCRIPTION & PRINCIPAL AUTHORS \\
\hline $\begin{array}{l}\text { Creating positions } \\
\text { with wide scope }\end{array}$ & $\begin{array}{c}\text { Jobs with a wide } \\
\text { scope, low horizontal } \\
\text { and vertical special- } \\
\text { izations. }\end{array}$ & $\begin{array}{c}\text { Schuler and Jackson (1987a); Capelli and Crocker-Hefter } \\
\text { (1996) }\end{array}$ \\
\hline $\begin{array}{l}\text { Selective recruit- } \\
\text { ment }\end{array}$ & $\begin{array}{l}\text { Defined recruitment } \\
\text { and selection criteria } \\
\text { appropriate to the } \\
\text { demands of the posi- } \\
\text { tion. Analysis of past, } \\
\text { present and future } \\
\text { conduct. }\end{array}$ & $\begin{array}{c}\text { Guest (1987), Arthur (1994), Pfeffer (1994), Huselid (1995); } \\
\text { Bayo and Merino (2001); Ordiz and Fenández (2003); Bel- } \\
\text { trán et al., (2008); Wood and Menezes (2008). }\end{array}$ \\
\hline Fixed contracting & $\begin{array}{l}\text { Job stability to avoid } \\
\text { temporary work. }\end{array}$ & $\begin{array}{l}\text { Pfeffer (1994); Bayo and Merino (2001); Ordiz and Fernán- } \\
\text { dez (2003); Wood and Menezes (2008) }\end{array}$ \\
\hline Extensive training & $\begin{array}{l}\text { Great importance } \\
\text { and investment in } \\
\text { the training and } \\
\text { development of the } \\
\text { employee. Contin- } \\
\text { uous and evaluated } \\
\text { training of all em- } \\
\text { ployees. Incentivise } \\
\text { skill acquisition. }\end{array}$ & Schuler and Jackson (1987a) \\
\hline
\end{tabular}




\begin{tabular}{|c|c|c|}
\hline $\begin{array}{c}\text { Performance eval- } \\
\text { uation }\end{array}$ & $\begin{array}{c}\text { Evaluation schemes } \\
\text { based on results. }\end{array}$ & $\begin{array}{l}\text { Guest (1987); Pfeffer (1994); Huselid (1995); Huselid et } \\
\text { al.,(1997); Capelli and Neumark (2001); Bayo and Merino } \\
\text { (2001); Richard and Johnson (2001); Gutrie et al., (2002); } \\
\text { Mohr and Zoghi (2008); Beltrán et al., (2008); Wood and } \\
\text { Menezes (2008) }\end{array}$ \\
\hline $\begin{array}{l}\text { Contingent com- } \\
\text { pensation }\end{array}$ & $\begin{array}{l}\text { Salary policies based } \\
\text { on individual and } \\
\text { group results. Reward } \\
\text { above the market } \\
\text { average. Tangible, in- } \\
\text { tangible and flexible } \\
\text { incentives. }\end{array}$ & $\begin{array}{c}\text { Guest (1987); Arthur (1994); Pfeffer (1994); Huselid (1995); } \\
\text { Bayo and Merino (2001);Capelli and Neumark (2001); } \\
\text { Gutrie et al.,(2002); Ordiz and Fernández (2003); Zatzick } \\
\text { e Iverson (2006); Beltrán et al.,(2008); Wood and Menezes } \\
\text { (2008) }\end{array}$ \\
\hline Greater discretion & $\begin{array}{l}\text { Award the position } \\
\text { and all its responsibil- } \\
\text { ities to the employee } \\
\text { in order to evaluate } \\
\text { conduct and norms in } \\
\text { the job. Decentraliza- } \\
\text { tion and less vertical } \\
\text { specialization. }\end{array}$ & $\begin{array}{l}\text { Schuler and Jackson (1987a and b); Arthur (1994); Pfeffer } \\
\text { (1994); Huselid (1995); Bayo and Merino (2001); Richard } \\
\text { and Johnson (2001); Gutrie et al., (2002); Ordiz and Fernán- } \\
\text { dez (2003); Mohr and Zoghi (2008). }\end{array}$ \\
\hline Internal promotion & $\begin{array}{l}\text { Provide opportuni- } \\
\text { ties for professional } \\
\text { development in the } \\
\text { company through } \\
\text { a formal system of } \\
\text { professional careers. }\end{array}$ & $\begin{array}{l}\text { Arthur (1994); Pfeffer, (1994); Huselid (1995); Bayo and } \\
\text { Merino (2001); Richard and Johnson (2001); Guthrie et al., } \\
\text { (2002); Ordiz and Fernández (2003); Mohr and Yoghi (2008) }\end{array}$ \\
\hline Teamwork & $\begin{array}{l}\text { Incentivize and } \\
\text { promote teamwork, } \\
\text { employee commit- } \\
\text { ment and Little job } \\
\text { rotation. }\end{array}$ & $\begin{array}{l}\text { Arthur (1994); Pfeffer (1994); Huselid et al., (1997); Bayo } \\
\text { and Merino (2001); Capelli and Neumark (2001); Richard } \\
\text { and Johnson (2001); Guthrie et al., (2002); Zatzick e Iverson } \\
\text { (2006); Mohr and Zoghi (2008) }\end{array}$ \\
\hline Shared information & $\begin{array}{l}\text { Open and shared } \\
\text { information systems } \\
\text { for all members of } \\
\text { the organization. }\end{array}$ & $\begin{array}{l}\text { Guest (1987); Arthur (1994); Pfeffer (1994); Huselid et al., } \\
\text { (1997); Capelli and Neumark (2001); Bayo and Merino } \\
\text { (2001) Richard and Johnson (2001); Guthrie et al.,(2002); } \\
\text { Ordiz and Fernández (2003); Zatzick e Iverson (2006); Mohr } \\
\text { and Zoghi (2008) Wood and Menezes (2008) }\end{array}$ \\
\hline Job security & $\begin{array}{l}\text { High levels of job } \\
\text { security. Specialized } \\
\text { staff to improve job } \\
\text { security. }\end{array}$ & Schuler and Jackson (1987 a and b) \\
\hline
\end{tabular}

Source: authors, based on Martí (2008)

Implementing all of these human resources practices has a deep impact on the employees and the teams because it increases his/her potential, motivation and commitment to the company (Sanchez, 2004), all of which are fundamental elements for improving innovation.

The commitment generated within the company makes the employee act in a positive manner, which translates into an effective way of achieving organizational objectives and 
leads to improved business results (Ordiz and Fernández, 2003; Mohr and Zoghi, 2008); Beltrán et al., 2008).

\section{METHODOLOGY}

To accomplishment of the present research, it has been used the case methodology. This is done to the main objective of carrying out a comprehensive analysis of the phenomenon. The importance of this methodology inside business management field and human resources area had been growing for the last years, due the implementation and influence from case methodology on surveys (e.g. Blanco and Gutiérrez, 2010; Miles and Snow, 1984). The use of this case methodology under the "best practices" way, had been traduce in a rutting activity inside of the current literature. But it has advantages and disadvantages.

This methodology lacking of statistical basis, it is an appropriate methodology for studies that seek to deepen in the how to carry out certain practices as intended in this research. (Yin, 2003) argues that case study is an empirical research that examines a contemporary phenomenon and it could contribute positively to the construction, improvement and development of rigorous theoretical models. The main problem with this approach is how to ensure the quality of data collected. It draws for a combination of different methods of data collection, as the literature offers.

In compliance with the requirements was selected for the study of SEMCO (currently the largest company manufacturing marine, and food processing machinery from Brazil). We have analyzed various publications about the company ${ }^{4}$, press dossier and economic background information was collected from the corporate web site ${ }^{5}$, because it makes explicit reference to who they are, what they do, their corporate values and organizational dynamics of the new management model. In addition, information was gathered through primary observation from researchers, and there have been several personal interviews focused on two directions, one by company executives ${ }^{6}$ and others oriented to different employees. Interviews were make from January to April of 2009, and were conducted following a semi-structured questionnaire made for this purpose. The average duration varies between 45 and 60 minutes and different employees were interviewed with greater and lesser responsibility. The objective is to provide to the present work of the reliability needed.

At Semco both, the target of the investigation, as the company itself, perfectly fit the assumptions that define (Yin, 2001) in their study. First, we intend to apply a theory that specifies a particular set of results in a specific situation, and the company has to be in that situation. Semco is a leader in its market that uses a different model for managing their staff, organizing its members in work teams. In this way, it is possible to use this methodology as a critical test of the theory and its applicability to the organization.

\footnotetext{
4 E.g. Semco Survival Manual

5 http://SEMCO.com.br/en/

6 For instance, some managers interviewed have been João Vendramim Neto (Partner and manager) and Flordelice Aparecida Fava Bassanello (Human Resource Manager).
} 
Second, when trying to study some specific features of an unusual situation, extraordinary or extreme in which the organization is, also it's possible to use this methodology. For Semco, the only possible way of working, to build competitive advantage is by using self-managed work teams. But we have to go deeper on how they are used and they manage to accomplish such results.

Finally, whether we pretend to study a situation or an organization that is unique in its nature can be possible use the case study methodology. On this case, we hope to learn something new and important.

\section{CASE STUDY: SEMCO, A BRAZILIAN COMPANY}

Semco is an example of a company that changed the way it does business by changing its relationship with its employees and it has long been a laboratory for unusual employment and management practices (Semler, 1994). This small international company is a "different company". They haven't an official structure, business plan or company strategy for two or five year plan. Nor have goal or mission statement, and no long-term budget. Semco does not have standards or practices, no human resources department because employees set their salaries and choose how and when they work, as well as the technology they work with (Semler, 2004a). They haven't career plans, no job descriptions or employer contract (Semler, 2007). Semco and Ricardo Semler (founder's entrepreneur son) turning it into one of the world's most unusual and admired workplaces, especially for their innovative practices in human resources management. With only 10 principles (e.g. organization chart, hiring, working hours, participaction, evalaution by subordinates, job security, communication,...) and value focus on open management and on human talent, and with a manual illustrated with 48 pages (named Semco Survival Manual), Semco has that it needs to manage the company.

\subsection{Semco history}

Semco was created in the 1950s, in Brazil, as a company manufacturing centrifuges for the vegetable oils industry (Semco, 2010). Australian engineer Antonio Curt Semler (Richard Semler's father) building of his invention, and patented it. He founded a small machine shop, which quickly became a two million dollar a year business. In the 60's Semco starts producing hydraulic pumps, load pumps, axles and other components for the naval industry.

Over the years, the company has modernized by expanding its range and investing in other businesses, until we have several divisions. In the 80s, with Richard Frank Semler (founder's son), Semco focus in a small number of customers (only shipyards) and then it started diversifying its businesses and purchases manufacturing licenses from other companies. When Richard Semler started to work, a new Semco company was developed. He began changing work habits, introducing ideas such as flexible hours, and he tries to motivate the staff (Semler, 2001).

When globalization begins, Semco moves into innovative service areas. Furthermore, Semco starts producing mixers for the chemical, pharmaceutical, food and mining indus- 
tries. But, in 1986, Semco changes to a centralized management system and starts operating with four strategic business units. In 90's, the company once again creates partnerships with well-known companies on the international market, for example: ERM Brazil (Environmental Resources Management, for environmental consultancy), Cushman \& Wakefield (real estate consultancy and facilities management market) or RGIS (to provide computerized inventories for retailers). When it began 2000, a part of the Group specialises in prospecting and developing new businesses: Semco Manutenção (providing electrical and civil maintenance and other services), BRENCO (Brazilian Renewable Energy Company),

Semco Group also holds strategic participations in other companies where it is one of the founding partners, Tarpon Investments (asset managers in Brazil to access the capital's market).

Now, Semco Group has two businesses: Industrial equipment, specializing in systems development and manufacture of equipment for mixing and cooling equipment, and Semco Pitney Bowes, a technology company specializing in "Mainstream" and world leader in solutions development, sales and maintenance of intelligent systems for automation and processing of correspondence and documents.

Semco has no products for the public. In most of its big contracts have a dozen clients, no more. Among its major customers include Alcoa, General Motors and Saab and Santander and Telefónica in Spain. Semco has gone from US\$ 4 to \$ 212 million since we started this system.

\subsection{Human resource model and manage teams in Semco}

Semco's philosophy is built on participation and involvement. Give opinions, seek opportunities and advancement, and always say what you think. Employees' don't just become one more in the company but their opinions are always interesting.

The company is looking for a profitable business concept, with democratic system, flexible working, responsibility and self-control. Semler's goal is to get people to take more control of their jobs, find solutions to their own problems and in doing so make the business go forward. The challenge is to get the middle of the organisation to make way for the freedom and lack of control for a system like ours to work (Semler, 2007).

Semco meets the characteristics of innovative teams, especially self-managing teams. For Example, in Semco all the work is organized and divided by self-managing teams. Members must perform their own tasks. Everything works through permanent and temporary teams. And they work in a large workspace. There is no allocation of offices and walls were torn down in the office to make a single room with one big space instead of many individual spaces. Workers put their desk where they want and use plants and flowers as dividers.

Semco tries to keep its company organized into smaller groups, so Semco's plants have less than 150 employees. Teams at these plants range from 5 to 20 employees. New entry level employees spend the first 6 months at the company moving from place to place (Baucus and Near, 1991).

Semco has implemented a system of circles: in which the inmost circle would enclose a team of half a dozen people, who will serve as a catalyst stimulating decisions and actions by those in the second circle, to be called Counselors. The second circle would enclose the 
leaders of Semco's business units and be called Partners. The last, immense circle would be comprised of everyone else and be called Associates. With triangles scattered about enclosing a single individual to be called Coordinators, who are the first crucial level of management. There would be six to twelve triangles floating about each business unit. As a consequence wages evened out and titles were simplified.

The main characteristic of Semco's team is than employees choose their managers. They decide among themselves who are the best member for manage the team and they decide the best way to make or go to work. Team's members redesign products they make, their work environments, and even formulate their own marketing plans. Managers run their units with unheard of freedom and determine business strategies without interference from top management (Semler, 2001). For example, workers took up the initiative to set up scoreboards in the manufacturing plants so that they could keep track of monthly goals they had set versus production, which allowed them to control the demand aspect of their job. This had the effect of improve the knowledge about the nature of demand.

All new initiatives change the way of make business in Semco; however, the biggest change was in the workers' ability to start making decisions for them. Responsibility and initiative became a significant part of the job requirement for the first time (Vanderbur, 2004).

Workers soon thereafter became a vital component in the control process. Workers control many facets of their job now, they rely on themselves to make important decisions to improve the company, and when employees are given control they act in their own best interest, which is the interest of the company (Semler, 2004a).

Employees can choose their own working hours (Semco, 2010). They also decide what their time of entry (usually 7 to 9 am), and although the working day is fixed at 8 hours, there is no control over it, being able to take several occasional breaks. Semco gives to its employees the freedom to customize their workdays (Semler, 2004a)

Other important aspect in Semco is job security. These mean that a worker that have been in Semco for three years, or have reached the age of fifty, has special protection and they can only be dismissed after a long series of approvals. It does not mean SEMCO has not layoff policy, but it helps to increase the security of their employees.

About the assessment in Semco, subordinates asses their bosses twice a year through a questionnaire filled out enabling each employee to express an opinion about his/her boss. Workers should be frank and honest, not just on the form but also in the discussion that follow it.

Semler thinks is fair to distribute the wealth with the workers who are now a significant part of the everyday of the company. Thus, profit sharing was initiated, and everyone receive the bonus, regardless of salary or job position. This has given people more job fulfilment, motivation and commitment. So, employees are not bored, unmotivated or unproductive. They train every day and they offer how improve their jobs with continuing challenges (Vanderburg, 2004).

In this way Semco gets a working environment flexible, because they want their people to feel free to change and adapt their working area as they want. The company has no rules, and does not intend to have any. People change their area according to their tastes and preferences according with other people desires. 
Semco awards much importance to training and development. Understanding financial account is necessary for all the employees in the company. Not only managers, all employees have to know about financial situation of the company. So, Semco designs an organization where employees develop their capabilities and trains employees to make key decisions understanding how their works contribute to improve the performance (Fort, 1997). The transparency with all the information is possible and it must be accessible to the employees. Semco strives the communication with frankness and honesty and it makes more humane the treatment of their workers. Workers are the company's best asset, and mutually beneficial relationships can and should exist (Vanderburg, 2004).

For all that we found very similar practices in Semco with high performance human resource practices, as it is shown in Table 2:

Table 2

Principal High Performance Human Resources Practices in Semco

\begin{tabular}{|l|l|l|}
\hline $\begin{array}{l}\text { HIGH PERFORMANCE } \\
\text { PRACTICES }\end{array}$ & \multicolumn{1}{|c|}{ SEMCO DESCRIPTION } & \multicolumn{1}{|c|}{ SOURCE } \\
\hline $\begin{array}{l}\text { Creating job with wide } \\
\text { scope }\end{array}$ & $\begin{array}{l}\text { No receptionists, secretaries or assistants, everyone } \\
\text { knows fax and photocopying. No matter how they do } \\
\text { things, matter what they do. No official structure. }\end{array}$ & $\begin{array}{l}\text { Semler, 1993 } \\
\text { Semler, 2004b } \\
\text { Questionnaire }\end{array}$ \\
\hline Selective recruitment & $\begin{array}{l}\text { Semco treats their employees "like adults" and selects } \\
\text { adult's employees. }\end{array}$ & $\begin{array}{l}\text { Semco Survival } \\
\text { Manual } \\
\text { Semler, 1993 }\end{array}$ \\
\hline Fixed contracting & $\begin{array}{l}\text { Indefinite hiring. Retire-a-little program where emplo- } \\
\text { yees are allowed to acquire early retirement. }\end{array}$ & $\begin{array}{l}\text { Semler, 2004b } \\
\text { Semler, 2007 }\end{array}$ \\
\hline Extensive training & $\begin{array}{l}\text { To further employee involvement, Semler encoura- } \\
\text { ged managers to trade jobs with one another so that } \\
\text { people would not grow restless, bored, unmotivated, or } \\
\text { unproductive }\end{array}$ & $\begin{array}{l}\text { Semler, 2007 } \\
\text { Semler, 1994 } \\
\text { Questionnaire }\end{array}$ \\
\hline Performance evaluation & $\begin{array}{l}\text { Workers soon thereafter became a vital component in } \\
\text { the control process. Workers were now in control of } \\
\text { very many facets of their job, relying on themselves to } \\
\text { make important decisions to better the company }\end{array}$ & Questionnaire \\
\hline $\begin{array}{l}\text { Contingent compensa- } \\
\text { tion }\end{array}$ & $\begin{array}{l}\text { The remuneration depends on the job, not while the } \\
\text { worker is working. No long-term wage offers but offers } \\
\text { jobs that are inherently more satisfying. Twice a year is } \\
\text { calculated on 23\% return after tax and a check is given } \\
\text { to three employees who have been elected by those } \\
\text { working in that division to invest that money until } \\
\text { the unit meets and decides by simple majority vote } \\
\text { what to do with it. In most divisions are decided equal } \\
\text { distribution }\end{array}$ & $\begin{array}{l}\text { Semco Survival } \\
\text { Questionnaire }\end{array}$ \\
\hline
\end{tabular}




\begin{tabular}{|l|l|l|}
\hline Greater discretion & $\begin{array}{l}\text { Semco philosophy is built on participation and } \\
\text { involvement. Give opinions, seek opportunities and } \\
\text { advancement, and always say what you think. The } \\
\text { employees don't just become one more person in the } \\
\text { company. Their opinion is always interesting, even if } \\
\text { no one asked them for it. Get in touch with the factory } \\
\text { committee and participate in elections. }\end{array}$ & $\begin{array}{l}\text { Semler, 2004a } \\
\text { Sanual } \\
\text { Semler, 2007 }\end{array}$ \\
\hline Internal promotion & $\begin{array}{l}\text { The assessment of their boss was made twice a year by } \\
\text { means of a questionnaire to be filled out enabling the } \\
\text { employees to express what they think about their boss. }\end{array}$ & $\begin{array}{l}\text { Semco Survival } \\
\text { Manual } \\
\text { Questionnaire }\end{array}$ \\
\hline Teamwork & $\begin{array}{l}\text { At Semco, the work to be done is organized and divided } \\
\text { by Self-managing teams. Members must perform their } \\
\text { own tasks. Everything works through permanent and } \\
\text { temporary teams }\end{array}$ & $\begin{array}{l}\text { Questionnaire } \\
\text { Semler, 1993 } \\
\text { Semler, 2001 }\end{array}$ \\
\hline Shared information & $\begin{array}{l}\text { The transparency with which as much information as } \\
\text { possible must be made accessible to the employee's, as } \\
\text { well as the means which allow for their comprehension }\end{array}$ & $\begin{array}{l}\text { Semco } \text { Survival } \\
\text { Manual } \\
\text { Questionnaire }\end{array}$ \\
\hline Job security & $\begin{array}{l}\text { Semco offer job security which is than any worker } \\
\text { that has been with them for three years, or has reached } \\
\text { the age of fifty, has special protection and can only be } \\
\text { dismissed after a long series of approvals. }\end{array}$ & $\begin{array}{l}\text { Semco Survival } \\
\text { Manual } \\
\text { Questionnaire }\end{array}$ \\
\hline
\end{tabular}

Source: authors, based on Semco information and different authors.

\section{CONCLUSIONS AND MANAGERIAL IMPLICATIONS}

The complexity and dynamism of the environments in which organizations now operate increase the possibility of creating innovative work teams that have very different characteristics to traditional work teams.

These new innovative teams share the same intent to obtain better results by making more and better use of the knowledge, skills and creativity of each of their members, regardless of the position they occupy, where they are located, the technology they use and the decision-making capacity they have. Innovative teams could be multifunctional teams, virtual teams open-innovation teams or self-managing teams.

In order for these teams to be effective, organizations need to incorporate new management tools that guarantee the integration of the members of teams and of the teams in their organizations. High performance practices or high commitment practices and skills management are seen as management techniques that have the potential to develop the individual skills of the different members of the organization and achieve increased integration and commitment. For instance, select responsible workers, well-trained and informed, also on financial aspects relevant for the company and with high level of confidence and freedom to take their own decisions, are the main keys on human resource management.

Once analysed the Semco company, it can be assessed the compliance with the targets of the study and show some conclusions. This company meets the characteristics of innovative teams, especially self-managing teams, for example: reduced size teams, complementary skills and abilities, commitment of all the members and shared responsibility for the results achieve. 
Therefore we found, concordance with the theory when it show us some factors related to the success of teamwork like: employee commitment, good communication, confidence, the feeling of belonging (Wellis et al, 1991), composition, participation, identify with the task and autonomy (West, 2002). All of this we found in Semco too.

In Semco, as we have seen before, self-managing teams are non-hierarchical groups of individuals with different and complementary experience and knowledge. Their objective is to develop a type of collective knowledge that requires the pooling of individual knowledge. No individual working alone could carry out the same tasks or produce the best innovations. For this reason companies turn to a combination of individuals with different and complementary skills and perspectives, deriving from this cooperation the achievement of these improvements and innovations.

According with Levin and Slem (1995), we have seen how human resource practices can help to improve the success of teamwork. In this case high performance human resource practices offer to the teams more qualification on its members, more commitment, a good assessment of the jobs, etc. All of this helps to create a pleasant work's environment and increase performance (Ichniowski et al, 1996).

But besides this, we have some questions which are important to improve effectiveness of work teams. First of all, a human resource model is a powerful tool to create a culture in organizations and it's useful to generate a good climate in work place, than not always the companies use. To obtain it, human resource model have to send similar messages. For example, companies cannot speak about performance task as a team and then have all evaluation of performance based on an individual level (Isaksenn and Lawer, 2002).

Secondly, teams need access to good quality and adequate information, but as well as training and educational support. If they don't understanding financial ratios, they can have access to the information but they don't know how their jobs contribute to generate this performance. So, it's very important focus on financial information and financial training, both of them.

Finally, we want focus on the aspect of the maturity in the employees. Only if we treat the employees as adults, they behave as adults. In Semco doesn't like treat its employees as adolescents who you have to say what have to do (Semler, 2004b).

If companies are looking for a sustainable and profitable business concept, they have use a human resource model according with the situation and establish a democratic system, with flexible work, focus on responsibility and initiative and increase the self-control of team's members.

\section{REFERENCES}

Anderson, N., De Creu, C.K.W., and Nijstad, B.A., 2004. The routinization of innovation research: A constructively critical review of the state-of-the-science. Journal of Organizational Behaviour. 25 (2), 147-173.

Arthur, J.B., (1994). Effects of human resource Systems on manufacturing performance and turnover, Academy of Management Journal, 37, 670-687.

Banker, R.D., Field, J.M., Schroeder, R.G. and Shina, K.K., 1996. Impact of work teams on manufacturing performance: A longitudinal field study. Academy of Management Journal, 39, 867-890. 
Baucus, M. S. and Near J. P., 1991. Can Illegal Corporate Behavior be Predicted? An Event History Analysis, Academy of Management Journal 34, 9-36.

Bayo, A. and Merino, J., 2001. Quality management and high performance work practices: do they coexist. International Journal of Production Economics, 73 (3), 251-260.

Beltrán, I., Roca, V., Escrig, A. and Bou, J.C. 2008. Human resource flexibility as a mediating variable between high performance work systems and performance. Journal of Management, 34 (5), 1009-1044.

Blanco, M. and Gutierrez, S., 2010. Application of the total quality management approach in a Spanish retailer: the case of Mercadona, Total Quality Management \& Business Excellence, 21(12), 1365 -1381.

Boudreau, K.J. and Lakhani, K.R., 2009. How to Manage Outside Innovation. MIT Sloan Management Review, Summer, 50 (4), 69-77.

Capelli, P. and Neumark, D., 2001. Do high-performance work practices improve establishment level outcomes?. Industrial and Labour Relations Review, 54 (4), 737-775.

Cappelli, P and Crocker-Hefter, A., 1996. Distinctive human resources are firm's core competencies. Organizational Dynamics, 24 (3), 7-22.

Chaston, I., 1998. Self-managed teams: Assessing the benefits for small service-sector firms. British Journal of Management. 9, 1-12.

Chesbrough, H., 2006. Open business models: How to drive in the new innovation landscape. Boston: Harvard Busi ness School Press.

Cohen, S. G. and Ledford, G. E. Jr., 1994. The effectiveness of self-managing teams: A quasi-experimental. Human Relations. 47, 13-43.

Cohen, S.G. and Bailey, D.E., 1997. What makes teams work Group effectiveness research from the shop floor to the executive suite. Journal of Management, 23, 239-290.

Cordery, J.L., Mueller, W.S. and Smith, L.M., 1991. Attitudinal and Behavioral Effects of Autonomous Group Working: a Longitudinal Field Study. Academy of Management Journal, pp. 464-476.

Curral, L.A., Forrester, R.H., Dawson, J.F. and West, M.A., 2001. It's What you do and the Way You Do It: Team Task, Team Size, and Innovation-related Group Processes. European Journal of Work and Organizational Psychology, 10, pp. 187-204.

De Jong, J.P.J., Vanhaverbeke, T., Chalet, T. and Chesbrough 2008. Policies for open innovation: theory, framework and cases. Helsinki, Finland: Research project funded by Vision Era-Net.

Drach-Zahavy, A., and Somech, A., 2001. Understanding team innovation: The role of team processes and structures. Group Dynamics-Theory Research and Practice 5 (2), 111-123.

Drazin, R. and Schoonhoven, C.B., 1996. Community Population, and Organizational Effects on Innovation: A Multilevel Perspective. Academy of Management Journal, 39 , pp. 1065-1083.

Fort, T. L., 1997. The Corporation as Mediating Institution: An Efficacious Synthesis of Stakeholder Theory and Corporate Constituency Statutes, Notre Dame Law Review 73, 173.

Grant, R., 1997. The knowledge-based view of the firm: implications for management practise. Long Range Planning. 30 (3), 450-454.

Guest, D.E., 1987. Human resource management and industrial relations. Journal of Management Studies, 24 (5), 503-521. 
Guthrie, J.P.; Spell, C.S. and Nyamori, R.O., 2002. Correlates and consequences of high involvement work practices: the role of competitive strategy. International Journal of Human resource Management, 13 (1), 183-197.

Gutierrez, S., 2012. Management and Leadership of Innovative Work Teams. In S. De Juana-Espinosa et al., (Eds.). Human Resource Management in the Digital Economy: Creating Synergy between Competency Models and Information. USA, IGI Global.

Huselid, M.A., 1995. The impact of human resource management practices on turnover, productivity, and corporate financial performance. Academy of Management Journal, 38, 673-703.

Huselid, M.A., Jackson, S.E. and Schuler, R.S, 1997. Technical and strategic human resource management effectiveness as determinants of firm performance. Academy of Management Journal, 40 (1), 171-188.

Hyatt, D.E. and Ruddy, T.M., 1997. An Examination of the Relationship between Work Group and Performance: Once More into the Breech. Personnel Psychology, p.555.

Ichniowski, C., Kochan, T.A., Levine, D., Olson, C., and Strauss, G., 1996. What works at work: overview and assessment. Industrial Relations, 35, 352-332.

Isacksen, S. and Lauer, K.T., 2002. The climate for creativity and change in teams. Creativity and innovation management, 11 (1), 74-86.

Joinson, C. 2002. Managing Virtual Teams: Keeping Members on the Same Page without Being in the Same Place Poses Challenges for Managers Workplace Trends. Human Resource Magazine, 47 (6), 68-72.

Kiffin-Peteron, S.A. and Cordery, J.L. 2003., Trust, Individualism, and Job Characteristics of Employee Reference for Teamwork. International Journal of Human Resource Management, pp. 93-116.

King, N. and Anderson, N., 2002. Managing Innovation and Change: A Critical Guide for Organizations. London: Thomson.

Kirkman, B. L. and Rosen, B., 1999. Beyond self-management: Antecedents and consequences of team empowerment, Academy of Management Journal. 42 (1), 58-74.

Kirkman, B. L., Gibson, C. B. and Shapiro, D. L., 2001. Exporting teams: Enhancing the implementation and effectiveness of work teams in global affiliates. Organizational Dynamics. 30 (1), 12-29.

Lawler, E.E., 1992. The ultimate advantage: creating the high-involvement organization. San Francisco: Jossey- Bass.

Levi, D. and Slem, C., 1995. Team work in research and development organizations: The characteristics of successful teams. International Journal of Industrial Ergonomics, 16, 29-42.

Marchington, M. and Grugulis, I., 2000.Best practice human resource management: perfect opportunity or dangerous illusion?. The International Journal of Human Resource Management, 11, (6), 1104-1121

Miles, R.E and Snow, C.C., 1984. Designing strategic human resource systems. Organizational Dynamics, vol. 31 (1), pp. 36-52.

Mohr, R.D. y Zoghi, C., 2008. The high-involvement work design and job satisfaction. Industrial and Labor Relations Review, 61, (3), 275-296.

Ordiz, M. and Fernández, E., 2003. High-involvement practices in human resource management: concept and factors that motive their adoption. International Journal of Human Resource Management, 14 (4), 511-529. 
Pearce, J.H., II and Ravlin, E.C., 1987. The design and activation of self-regulating work groups. Human Relations, 40, 751-782.

Perretti, F., and Negro, G., 2007. Mixing genres and matching people: A study in innovation and team composition in Hollywood. Journal of Organizational Behaviour. 28 (5), 563-586.

Pfeffer, J., 1994.Competitive advantage through people. California Management Review, 36 (2), 9-28.

Richard, O.C. and Johnson, N.B., 2001. Strategic Human Resource Management Effectiveness and firm performance. The International Journal of Human resource Management, 12, 299-310.

Rubio, M., Gutiérrez, S and Varona, L 2013. Self-managing teams in small and medium enterprises, in Machado and Melo (Eds). Effective Human Resources Management in Small and Medium Enterprises: Global Perspective. USA, IGI Global. 280-300

Sashkin, M. 1984. Participative management is an ethical imperative, Organizational Dynamics, 12 (4), 5-22.

Schuler, R.S., and Jackson, S.E., 1987a. Linking competitive strategy with human resource management practices. Academy of Management Executive, 1 (3), 207-219.

Schuler, R.S., and Jackson, S.E., 1987b. Organizational strategy and organization level as determinants of human resource management practices. Human Resource Planning, $10(3), 125-141$.

Semco, 2010. The Semco business Model, http://semco.com.br/en/ (accesed on $12^{\text {th }}$ july 2011).

Semler, R., 1993. Maverick: The success store behind the world's most unusual workplace. New York, Warner Books.

Semler, R., 1994. Why My Former Employees Still Work for Me, Harvard Business Review, January-February 1994. Reprint \#94112.

Semler, R 2001. Latest whys and wherefores of the maverick, Financial Times, Oct 18, London Edition.

Semler, R., 2004a. The Seven-Day Weekend: Changing The Way Work Works. New York: Warner Books.

Semler, R., 2004b. What a nimble, motivated workforce? Cio insight, Apr 1, 2004, New York

Semler, R, 2007: Out of this World: Doing things the Semco way, Global Business and Organizational Excellence, July/August, pp. 13-21.

Terreberry, S., 1968. The evolution of organizational environments. Administrative Science Quarterly, 20, 590-613

Townsend, A.M., DeMarie, S.M. and Hendrickson, A.R., 1998. Virtual teams: Technology and the workplace of the future. Academy of Management Executive, 12 (3), 17-29.

Truss, C., Gratton, L., Hope-Hailey, V., McGovern, P. and Stiles, P., 1997. Soft and hard models of human management: a reappraisal. Journal of Management Studies, 34, 53 73.

Tushman, M.L. and O’Reilly, C.A., 1997. Winning through Innovation. Cambridge, MA: Harvard Business School Press.

Van Knippenberg, D. and Schippers, M.C., 2007. Work group diversity. Annual Review of Psychology. 58, 515-541 
Vanderburg D 2004. The Story of Semco: The Company that Humanized Work, Bulletin of Science Technology Society; 24; 430

Wall, T. D., Kemp, N. J., Jackson, P. R., and Clegg, C. W. 1986. Outcomes of autonomous workgroups: A long-term field experiment. Academy of Management Journal, 29(2), 280-304.

Wellis, R.; Byham, W. and Wilson, J. M.. 1991. Empowerment teams: Creating self-directed work groups that improve quality, productivity and participation. San Francisco, CA: Jossey-Bass.

West, M.A., 2002. Sparkling fountains or stagnant ponds: An integrative model of creativity and innovation implementation in work groups. Applied Psychology-an International Review-Psychologies Appliquee-Revue Internationale. 51 (3), 355-387.

West, M.A., y Hirst, G., 2003. Cooperation and teamwork for innovation. En M.A. WEST, D. Tuosvold y K.G. Smith (Eds.), International handbook of organizational teamwork and cooperative working, 297-319. Chichester, England: Wiley.

Wood, S. and de Menezes, L.M., 2008. Comparing perspectives on high involvement Management and organizational performance across the British economy. The International Journal of Human Resource Management, 19 (4), 639-682.

Wright, P. M., McMahan, C. and McWilliams, A., 1994. Human resources and sustained competitive advantage: A resource-based perspective. International Journal of Human Resource Management, 5 (2), 301-326.

Yang, S-B. and Guy, M., 2011. The effectiveness of self-managed work teams in Government Organizations. Journal of Business Psychology, 26, 531-541.

Yin, R.K., 2003. Case Study Research. Thousands Oaks. Sage Publications.

Zatzick, C.D. and Iverson, R.D. 2006. High-involvement management and workforce reduction: competitive advantage or disadvantage?, Academy of Management Journal, 49 (5), 999-1015. 
